Western University Scholarship@Western

Centre for the Study of International Economic

Centre for the Study of International Economic

Relations Working Papers

Relations

1985

\title{
A Dynamic Equilibrium Model of Asset Prices and Transaction Volume
}

GregoryW. Huffman

Follow this and additional works at: https://ir.lib.uwo.ca/economicscsier_wp

Part of the Economics Commons

Citation of this paper:

Huffman, Gregory W.. "A Dynamic Equilibrium Model of Asset Prices and Transaction Volume." Centre for the Study of International Economic Relations Working Papers, 8517C. London, ON: Department of Economics, University of Western Ontario (1985). 
ISSN 0228-4235

ISBN 0-7714-0663-0

CENTRE FOR THE STUDY OF INTERNATIONAL ECONOMIC RELATIONS

WORKING PAPER NO. $8517 \mathrm{C}$

A DYNAMIC EQUILIBRIUM MODEL OF

ASSET PRICES AND TRANSACTION VOLUME

Gregory W. Huffman

This paper contains preliminary findings from research work still in progress and should not be quoted without prior approval of the author.

DEPARTMENT OF ECONOMICS

THE UNIVERSITY OF WESTERN ONTARIO

LONDON, CANADA

N6A $5 \mathrm{C} 2$

Department of Economics Library

Ser $6 \quad 1985$

University of Western Ontario 


\title{
A DYNAMIC EQUILIBRIUM MODEL OF
}

\section{ASSET PRICES AND TRANSACTION VOLUME}

\author{
Gregory W. Huf fman
}

Department of Economics

University of Western Ontario

London, Canada

August, 1985

I would like to thank Dominique Demougin for doing the calculations. All remaining errors are my own.

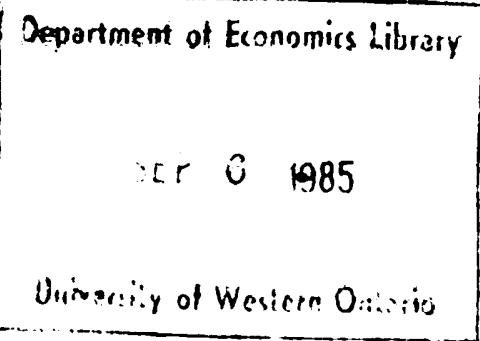


A dynamic general equilibrium model of capital asset pricing is constructed in which the volume of capital traded is determined endogenously. The model also gives rise to a novel asset-pricing formula. It is shown that a shock to, say, dividends can give rise to serially correlated changes in the price of capital and transaction volume which persist long after the initial shock. The implications the model has for explaining asset price volatility are also explored. 


\section{Introduction}

This paper studies the behaviour of asset markets within the context of a dynamic general equilibrium model. This model gives rise to an interesting asset pricing formula as well as novel implications for the temporal behaviour of asset prices. In addition the volume of shares of capital traded in a period will be determined endogenously. This represents an important advance over existing equilibrium models which are reticent concerning the determinants of transaction volume.

A theoretical construct which is used to study a wide range of issues in finance is the representative agent model. It is used in both general equilibrium (e.g. Lucas (1978)) and partial equilibrium models (e.g. Merton 1973)). A possible unfortunate consequence of this line of attack is that, by assumption, all agents are identical. Consequently, the quantity of assets traded in any period is essentially zero. Hence such a model seems incapable of yielding insights into the determinants of the volume of assets traded.

Recent work has been devoted to the study of the behaviour of asset prices in environments in which there is a heterogeneous population (see for example Huberman (1984) and Huffman (1983, 1984)). In particular, this work utilizes the two period lived overlapping generations paradigm. An unfortunate by-product of this model is that, although assets are traded from agent to agent, in fact, all assets are traded every period. That is, the volume of assets traded is constant for all realizations of the sample space. Hence, it would seem that existing equilibrium models lack any interesting implications for the volume of assets traded. Isolating the factors which 
influence the transactions volume would seem to be important because these factors are also likely to affect the prices and rates of return in the economy. In other words, the stochastic process governing such variables as asset prices, volume of trade, and rates of return are generated jointly by the factors which determine the stochastic structure of the environment which agents face. Hence any factor which influences one endogenous variable, such as the volume of trade, is also likely to impinge upon other endogenous variables, such as the level of asset prices. Therefore models which yield a trivial transactions volume may be ignoring one of the more interesting features of asset markets.

Existing studies of the behaviour of transactions volume in asset markets have been primarily empirically oriented. Epps (1975) investigated the relationship between the transactions volume and price changes when prices rise, as opposed to when prices fall. Epps found that the distribution of the ratio of transactions volume to the absolute value of the price change, when prices rose, was different than for the same ratio when prices fell. Tauchen and Pitts (1983) as well as Ying (1966), have found that the volume of transactions tends to be positively related to the absolute value of price changes. However, as previously mentioned, it appears to be difficult to build a dynamic equilibrium model which is consistent with these facts. The present paper is an attempt to bridge this gap.

Because a major portion of the existing equilibrium models of asset pricing have employed the representative agent construct, this work has ignored an important factor which can influence the level of asset prices: namely, the degree to which the population is heterogeneous. It can be easily established that a model with a heterogeneous population can yield different 
"behaviour" than can a similar model which utilizes the representative agent construct. The present paper will present a model in which the level of asset prices, rates of return, and transactions volume are all affected by the existing distribution of capital holdings among the heterogeneous population. Further, a temporary shock to, say, endowments can produce variability in the price of capital which persists for many periods. This same temporary shock can also cause the price to exhibit persistent serial correlation in subsequent periods. These factors do not influence the price of capital in existing models.

The remainder of this paper is organized as follows. In Section II the physical environment of the economy is specified. Agents live for $n$ periods, where $2<n<\infty$, and are endowed with some of the consumption good in the first period of their life. They may purchase units of productive capital which enable them to consume in future periods. The agent's optimization problem is specified and solved. The resulting equilibrium asset pricing equation is derived, as are the optimal portfolio holdings of all agents.

In Section III the steady-state characteristics of the model are explored. Section IV details the dynamic implications of the model. It is shown that a shock to the economy can produce cyclical behaviour in the endogenous variables which appears to be rather novel. The implications the model has for excess price variability are explored in section $v$. It is shown that the model can produce variability in the price of capital, which continues over many periods, and is not the result of any changes in dividends or aggregate consumption. Final remarks are contained in section VI. 
II. The Physical Environment

This section describes an economy in which time is discrete and is indexed by $t=1,2, \ldots$. At each date $(t)$ there are born $M$ identical agents. Each agent lives for $\mathbb{N}$ periods where $2<\mathbb{N}<\infty$. An individual born in period $(t)$ is endowed with $y_{t}$ units of the consumption good in period $(t)$ and receives no other such endowment in any subsequent period. Each agent who is a member of generation ( $t$ ) seeks to maximize the expected value of the discounted finite sum of utilities

$$
\left.E \sum_{i=0}^{N-1} \sum^{i} \ln \left(c_{1+i}^{t+i}\right)\right\}, \quad \beta>0
$$

Here $c_{1+i}^{t+i}$ refers to period $(t+i)$ consumption of an agent born in period $(t)$. In this economy there exists $\mathrm{K}$ units of non-augmentable, non-depreciable capital. Each unit of capital yields an exogenous dividend $d_{t}$, in units of the consumption good, in each period $(t)$. Both $y_{t}$ and $d_{t}$ are random variables which are not known prior to the appearance of generation $(t)$. Let $\phi_{t} \equiv\left(y_{t}, d_{t}\right)$ denote the composite stochastic variable for the economy at time (t). The distribution of $\phi_{t}$ will be determined by a transition distribution function $F\left(\phi_{t} \mid \phi_{t-1}\right)$.

An agent who is a member of generation ( $t$ ) may also wish to purchase $x_{1+i}^{t+i}$ units of capital, in period $t+i(i=0,1,2 \ldots N-2)$, for the price $P_{t+i}$, which is denominated in units of the consumption good. In period $(t+i+1)$ such an agent would receive the dividend yielded by the security, $x_{1+i}^{t+i} \cdot d_{t+i+1}$ plus proceeds from the sale of capital holdings $x_{1+i}^{t+i} \cdot P_{t+i+1}$. The agent can then use these proceeds to consume, or purchase more capital for future consumption. Clearly, an agent who is in the last period of his life will not purchase more capital. 
At date $t=1$ there are $M(N-1)$ agents whose behaviour has not yet been described. There are $M$ agents who will live $n$ periods for each $n=1,2, \ldots N-1$. An agent who lives only $n$ more periods, including period $t=1$, maximizes the utility function

$$
\sum_{i=1}^{n} \beta^{i-1} \ln \left(c_{N-n+i}^{i}\right)
$$

where $c_{\mathrm{N}-n+i}^{i}$ denotes period (i) consumption of an agent who, at time $t=1$, lives for only $n$ more periods. At time $t=1$ an agent who lives from period 1 until period $n$, where $1 \leqq n \leq \mathbb{N}$, currently holds $x_{N-n+1}^{1} \geqq 0$ units of capital. Equilibrium in this asset market implies that

$$
\mathbf{n} \sum_{n=1}^{N-1} x_{\mathbb{N}-n+1}^{1}=K \text {. }
$$

Since all members of a generation are identical, it will simplify the analysis, with no consequent loss of generality, if it is assumed that $M=1$, so that each generation consists of a single representative individual. The population, however, is still heterogeneous because of the different lifetimes, and possibly different portfolios which agents possess. It should be noted that the subsequent analysis could be expanded to account for stochastic population size with the only cost being the additional notational complexity.

With the above discussion in mind, an agent who is a member of generation $t(t=1,2, \ldots)$ then solves the following problem

$$
\max E_{t}\left\{\sum_{i=0}^{N-1} \beta^{i} \ln \left(c_{1+i}^{t+i}\right)\right\}
$$

subject to the constraints

$$
\begin{aligned}
& c_{1}^{t}=y_{t}-x_{1}^{t} \cdot P_{t} \\
& c_{1+i}^{t+i}=x_{i}^{t+i-1} \cdot\left(P_{t+i}+d_{t+i}\right)-x_{1+i}^{t+i} \cdot P_{t+i} \text {, for } i=1,2, \ldots, N-2
\end{aligned}
$$




$$
c_{N}^{t+N-1}=x_{N-1}^{t+N-2} \cdot\left(P_{t+N-1}+d_{t+N-1}\right)
$$

This problem must be solved recursively to find the optimal capital holdings in each successive period. In period $(t+\mathbb{N}-2)$ an agent who is a member of generation ( $t$ ) will choose $x_{\mathrm{N}-1}^{t+n-2}$ in such a way that

$$
\left[\frac{P_{t+N-2}}{x_{N-2}^{t+N-3} \cdot\left(P_{t+N-2}+d_{t+N-2}\right)-x_{N-1}^{t+N-2} \cdot P_{t+N-2}}\right]=\left[\frac{\beta}{x_{N-1}^{t+N-2}}\right]
$$

which does not involve an expectation operator. Similarily, for time $(t+j-1)$ for $j=2,3, \ldots . N-2$, the necessary conditions for the solution to the agent's optimization problem are:

$$
\begin{gathered}
\left(\frac{P_{t+j-1}}{x_{j-1}^{t+j-2} \cdot\left(P_{t+j-1}+d_{t+j-1}\right)-x_{j}^{t+j-1} \cdot P_{t+j-1}}\right)= \\
B_{t+j-1}\left(\frac{B\left(P_{t+j}+d_{t+j}\right)}{x_{j}^{t+j-1} \cdot\left(P_{t+j}+d_{t+i}\right)-x_{1+j}^{t+j} \cdot P_{t+j}}\right)
\end{gathered}
$$

Lastly, for time period $(t)$ the agent must have

$$
\left(\frac{P_{t}}{y_{t}-x_{1}^{t} \cdot P_{t}}\right)=E_{t}\left(\frac{\beta\left(P_{t+1}+d_{t+1}\right)^{t}}{x_{1}^{t} \cdot\left(P_{t+1}+d_{t+1}\right)-x_{2}^{t+1} \cdot P_{t+1}}\right)
$$

Equation (4) implies

$$
x_{N-1}^{t+N-2} \cdot P_{t+N-2}=\left[\frac{\beta}{1+\beta}\right]\left[x_{N-2}^{t+N-3} \cdot\left(P_{t+N-2}+d_{t+N-2}\right)\right],
$$

which together with equation (2) implies

$$
c_{N-1}^{t+N-2}=\left[\frac{1}{1+\beta}\right]\left[x_{N-2}^{t+N-3} \cdot\left(P_{t+N-2}+d_{t+N-2}\right)\right] .
$$


Substitution of equation ( 7 ) into equation (5) for $\mathrm{j}=\mathrm{N}-2$ yields

$$
x_{N-2}^{t+N-3} \cdot P_{t+N-3}=\left[\frac{\beta+\beta^{2}}{1+\beta+\beta^{2}}\right]\left[x_{N-3}^{t+N-4} \cdot\left(P_{t+N-3}+d_{t+N-3}\right)\right] \text {, }
$$

which together with equation (2) yields

$$
c_{N-2}^{t+N-3}=\left[\frac{1}{1+\beta+\beta}\right]\left[x_{N-3}^{t+N-4} \cdot\left(P_{t+N-3}+d_{t+N-3}\right)\right]
$$

It is of some interest to note that the substitution removes the expectation operator since all variables on the right side of the equation are known at time $(t+\mathbb{N - 3})$. In general, for an economy in which agents live for $\mathbb{N}$ periods, recursive substitution of equations (5) and (6) will yield the following solutions for saving and consumption for $i=1,2, \ldots . N-2$

$$
\begin{aligned}
& \left.x_{N-i}^{t+N-i-1} \cdot P_{t+N-i-1}=\left[\frac{\sum_{j=0}^{i-1} \beta^{j+1}}{\sum_{j=0}^{i} \beta^{j}}\right]{ }_{N-i-1}^{t+N-i-2} \cdot\left(x_{t+N-i-1}+d_{t+N-i-1}\right)\right], \\
& c_{N-i}^{t+N-i-1}=\left[\frac{1}{\sum_{j=0}^{i} \beta^{j}}\right]\left[x_{N-i-1}^{t+N-i-2} \cdot\left(P_{t+N-i-1}{ }^{t+N-i-1} d_{t+N-1}\right)\right]
\end{aligned}
$$

Lastly, equation (6) together with equations (9) and (10) for $i=N-2$ yields

$$
x_{1}^{t} \cdot P_{t}=\left[\frac{\sum_{j=1}^{N-1} \beta^{j}}{\sum_{j=1}^{N} \beta^{j-1}}\right] y_{t},
$$

and

$$
c_{1}^{t}=\left[\frac{1}{\sum_{j=1}^{N} \beta^{j-1}}\right] y_{t} .
$$


Equilibrium in the market for capital dictates that

$$
P_{t} \cdot \sum_{j=0}^{N-2} x_{1+j}^{t}=P_{t} \cdot K
$$

Equations (9) and (11) then imply that the market clearing condition is

$$
\left[\frac{\sum_{j=1}^{N-1} \beta^{j}}{\sum_{j=1}^{N} \beta^{j-1}}\right] y_{t}+\sum_{i=1}^{N-2}\left[\left[\frac{\sum_{j=0}^{N-i-2} \beta^{j+1}}{\sum_{j=0}^{N-i-1} \beta^{j}}\right]\left(x_{i}^{t-1} \cdot\left(P_{t}+d_{t}\right)\right)\right]=P_{t} \cdot k .
$$

The equilibrium price of capital is then

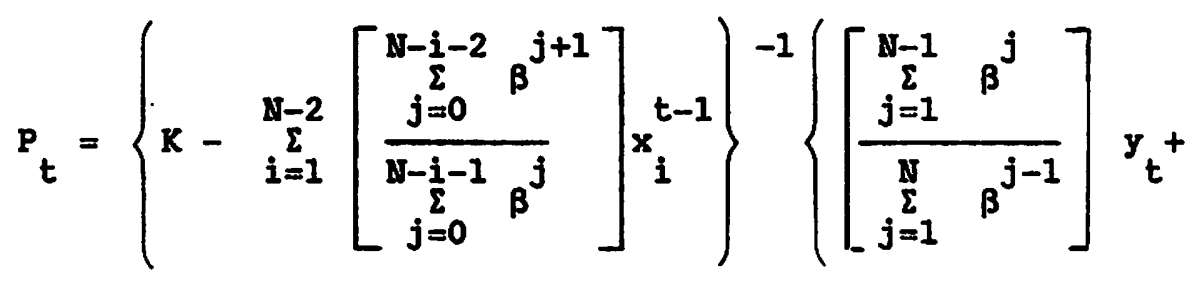

$$
\begin{aligned}
& \underset{i=1}{N-2}\left[\frac{\sum_{j=0}^{N-2} \beta^{j+1}}{\sum_{j=0}^{i-1} \beta^{j}}\right] x_{i}^{t-1} \cdot d t_{t}
\end{aligned}
$$

Equation (13) is a reduced form function which shows how the price of capital depends upon existing state variables at time $(t)$--namely the dividend $\left(d_{t}\right)$, non-dividend endowments $\left(y_{t}\right)$, and capital holdings from the previous period $x_{i}^{t-1}, i=1,2 \ldots \ldots N-2$. Similarly equations (7) through (12) list the reduced form functions for individual consumption and saving which depend upon existing state variables.

There are several interesting features which this pricing function exhibits. A possible criticism of this formula is that expectations play no 
role, and hence the distribution of future income or dividends is irrelevant for the price this period. This is attributable merely to the logarithmic form of the utility function. Equation (13), however, displays a particular feature which is novel when compared to existing asset pricing formulas derived from equilibrium models (see Lucas (1978) and Huberman (1984)). It can be seen that the distribution of existing capital among the population of agents in the economy has an influence on the price of capital. Different distributions of capital amongst the population will yield a different price for a given realization of $\left(d_{t}\right)$ and $\left(y_{t}\right)$. In most existing equilibrium models the pricing formula can generally be written as a function of the (usually stochastic) state variables of the model. Equation (13), however, indicates that when agents live for three or more periods, the capital holdings of existing agents in the economy must also be included in the relevant state vector for the pricing function.

For an agent born in period $t$, the change in his or her holdings of capital from period $(t+i)$ to period $(t+i+1)$ is

$$
\left(x_{i+2}^{t+i+1}-x_{i+1}^{t+i}\right) \text {. }
$$

If this quantity is positive, the agent is accumulating capital across periods, and if it is negative the agent is a net seller of capital. Hence the quantity of capital transacted from period ( $t-1)$ through period ( $t$ ) may be defined as

$$
\begin{aligned}
v_{t} & =x_{1}^{t}+\sum_{i=2}^{N-1} \max \left\{\left(x_{i}^{t}-x_{i-1}^{t-1}\right), 0\right\} \\
& =x_{N-1}^{t}+\sum_{i=2}^{N-1} \max \left\{\left(x_{i-1}^{t-1}-x_{i}^{t}\right), 0\right\} \\
& =(1 / 2)\left\{x_{t}^{1}+x_{N-1}^{t}+\sum_{i=2}^{N-1}\left\{x_{i}^{t}-x_{i-1}^{t-1} \mid\right\} .\right.
\end{aligned}
$$


The first term merely defines the sum of the changes in the quantity of capital held by agents who are net purchasers of assets. Since the quantity of capital is fixed, this must also equal the sum of the changes in the quantity of capital held by agents who are net sellers of assets, which is the second term in the definition. The last term merely makes use of the previous two definitions, and reflects the idea that for each unit of capital that changes hands there is both a sale and a purchase.

Instead of thinking of an agent, born in period $(t)$, as selling all capital holdings $x_{i-1}^{t+i-2}$, in period $(t+i-1)$, and purchasing $x_{i}^{t+i-1}$, consider the following specification. Such an agent may be thought of as holding $x_{i-1}^{t+i-2}$ units of capital at the beginning of period $(t+i-1)$ and buying $\left(x_{i}^{t+i-1}-x_{i-1}^{t+i-2}\right)$ units of capital in this period if $\left(x_{i}^{t+i-1}-x_{i-1}^{t+i-2}\right)>0$, or selling $\left(x_{i-1}^{t+i-2}-x_{i}^{t+i-1}\right)$ units of capital if $\left(x_{i}^{t+i-1}-x_{i-1}^{t+i-2}\right)<0$. $v_{t}$ then denotes the total volume of capital transacted in this period $(t)$. That is, the sale of a unit of capital by one agent, and the purchase of the same unit by another agent will be counted as only one transaction. 1

\section{The Steady State}

An interesting benchmark to consider is one in which the dividend $\left(d_{t}\right)$ and the non-dividend endowment $\left(y_{t}\right)$ are time-invariant. Although the capital holdings $\left(x_{i}^{t}\right)$ will be time-invariant as well, they will still be functions of the individual's age. Hence the agent's holdings of capital may vary over his lifetime. In this case the previous analysis of equations (7) through (13) goes through with the time, but not age, subscript omitted. This will be done throughout the present section.

The preceding analysis may be helpful in determining the circumstances under which agents will be purchasing $\left(x_{i}-x_{i-1}>0\right)$ or selling capital. 
Equation (9) now takes the form

$$
x_{N-i}^{P}=\left[\frac{\sum_{j=0}^{i-1} \beta^{j+1}}{\sum_{j=0}^{i} \beta^{j}}\right]\left[x_{N-i-1} \cdot(P+d)\right]
$$

or

$$
\left(x_{N-i}-x_{N-i-1}\right) P=\left[\frac{x_{N-i-1}}{\sum_{j=0}^{i} \beta^{j}}\right]\left[\sum_{j=0}^{i-1} \beta^{j+1} d-P\right]
$$

which is of indeterminate sign. However, the steady state versions of equations (7), (9), (11) and (13) reveal that the price of capital is jointly homogeneous of degree one in (d) and $(y)$, while the equilibrium holdings of capital $x_{N-i}, i=1,2 \ldots . N-1$, are homogeneous of degree zero jointly in both (d) and (y). Equation (15) would then seem to indicate that the greater is d relative to $y$, the greater will be the quantity of capital held in the (N-i) th period of the agent's life relative to the $(N-i-1)^{\text {th }}$ period. This is important because it indicates that an agent may be expected to run down on his holdings of capital as he gets older. This result seems very intuitive in such a steady state economy. If instead an agent continued to accumulate capital, or even hold constant his portfolio, then as he approached the end of their time horizon he would be consuming the dividends from a non-decreasing stock of capital. In the final period the agent would consume the dividends, which alone should be at least as much as the previous period's level of consumption, plus the proceeds from the sale of capital. In 
other words, in a steady state an agent who may discount the future and wishes to smooth consumption over time will then consume substantially more in the final period relative to previous period. Since this is clearly not an optimal strategy, an agent should begin to run down on his stock of capital at some date before the end of the agent's lifetime. Intuition suggests that the larger the value of $(y)$ relative to (d), the sooner the individual is likely to cease becoming a net purchaser of capital and to start selling capital. In fact, for very large values of $y$, the individual may purchase a great deal of capital in the first period of his or her life (see equation (11)), and run down on it for the remainder of the planning horizon.

This is illustrated in Figure (1). In this diagram the steady state values of capital holdings for agents of different ages is plotted in four different steady state economies. For high values of $y$, the individual may purchase a lot of capital in the first period of his life and run down on it thereafter. The illustration shows that for low values of $y$, the individual may purchase capital for several periods before beginning to run down on his portfolio. It should be of no surprise that the higher is the value of $(y)$, the higher is the price of capital. In this model, steady state economies with high values of $(y)$ exhibit similiar behaviour to those with relatively low values of $d$. That is, what is important for the path of an individual's capital holdings is the relative value of (y) to (d), for a given quantity of capital stock. A diagram similar to that of Figure (1) could be used to show the effect of changes in dividends. Such an illustration would show that for low values of (d) the agents are likely to start running down on their portfolios earlier in their lifetime. 


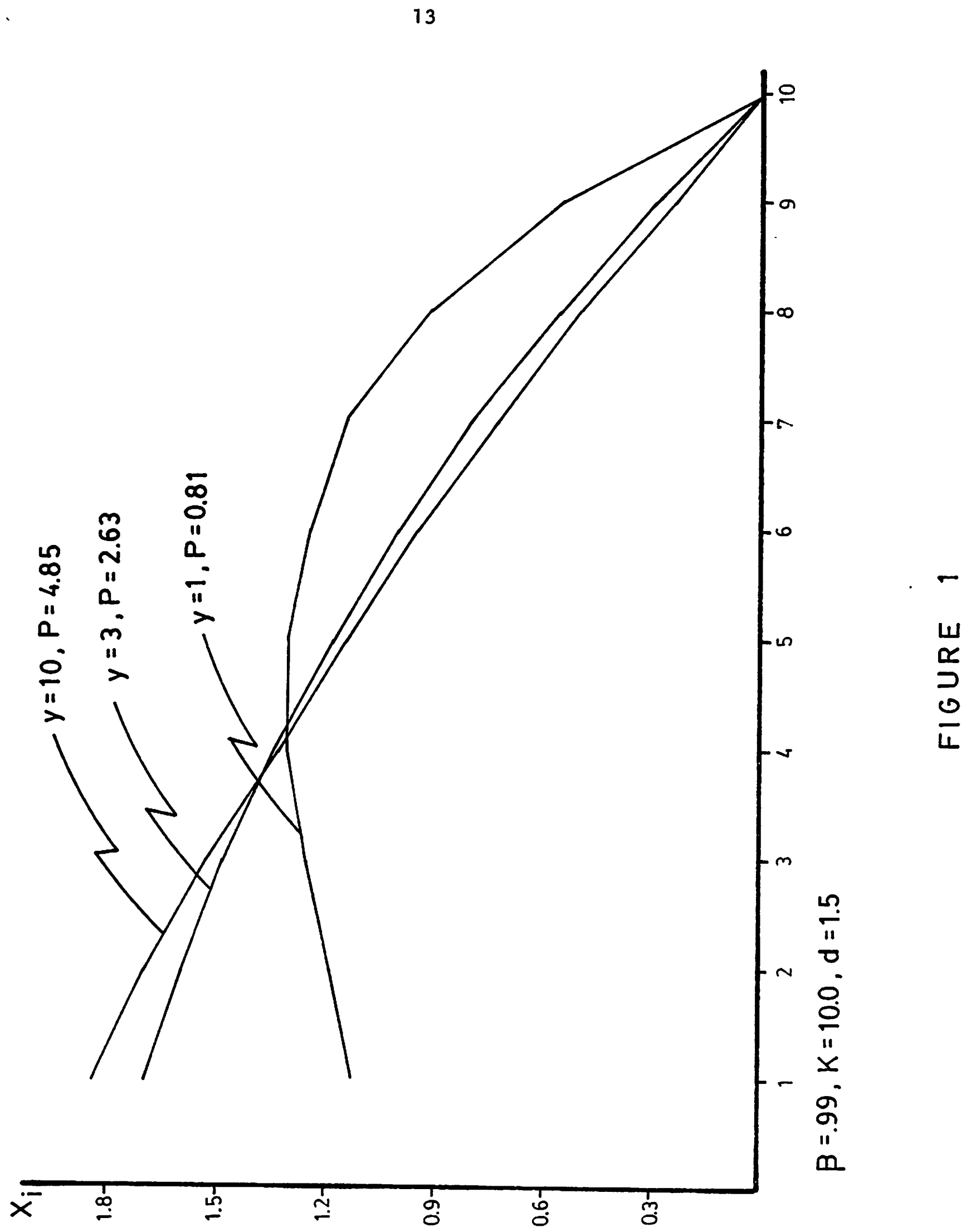


Figure (2) shows how the agent's lifetime portfolio changes as the discount rate changes. As the agent's discount rate rises, that is, as the agent become less myopic, he will purchase less capital initially (because of its higher price), but will eventually hold a greater quantity of capital before beginning to run down on their portfolio. It is also clear that the greater is the value of $\beta$, the greater will be the steady state value of a unit of capital, and the greater will be the agent's desire to transfer wealth to future periods. Hence higher steady state values of the price of capital are associated with higher discount factors.

\section{Dynamics}

As was mentioned in Section II, the pricing function (equation (13)) displays some novel features when compared to pricing functions in the existing literature. In particular, the distribution of capital holdings among the population will influence the price of capital. As an illustration, consider the perverse case where $x_{1}^{t-1}=K$ and $x_{i}^{t-1}=0$ for $i=2,3, \ldots . N-2$. That is, the youngest generation holds all the capital. Then the pricing function takes the form

$$
P_{t}=\left\{\frac{K}{\sum_{j=0}^{N-2} \beta^{j}}\right\}^{-1}\left\{\left[\frac{\sum_{j=1}^{N-1} \beta^{j}}{\sum_{j=1}^{N} \beta^{j-1}} y_{t}+\left[\frac{\sum_{j=0}^{N-3} \beta^{j+1}}{\sum_{j=0}^{N-2} \beta^{j}}\right] x \cdot d_{t}\right\}\right.
$$

Alternatively, if the generation of age (N-1) own all the capital then $x_{N-2}^{t-1}=K$ and $x_{i}^{t-1}=0$ for $i=1,2, \ldots N-3, N-1$. It follows that

$$
P_{t}=\left[\frac{1+\beta}{K}\right]\left\{\left[\frac{\sum_{j=1}^{N-1} \beta^{j}}{\sum_{j=1}^{N} \beta^{j-1}}\right] y_{t}+\left(\frac{\beta}{1+\beta}\right) K \cdot d_{t}\right\} \text {. }
$$


15

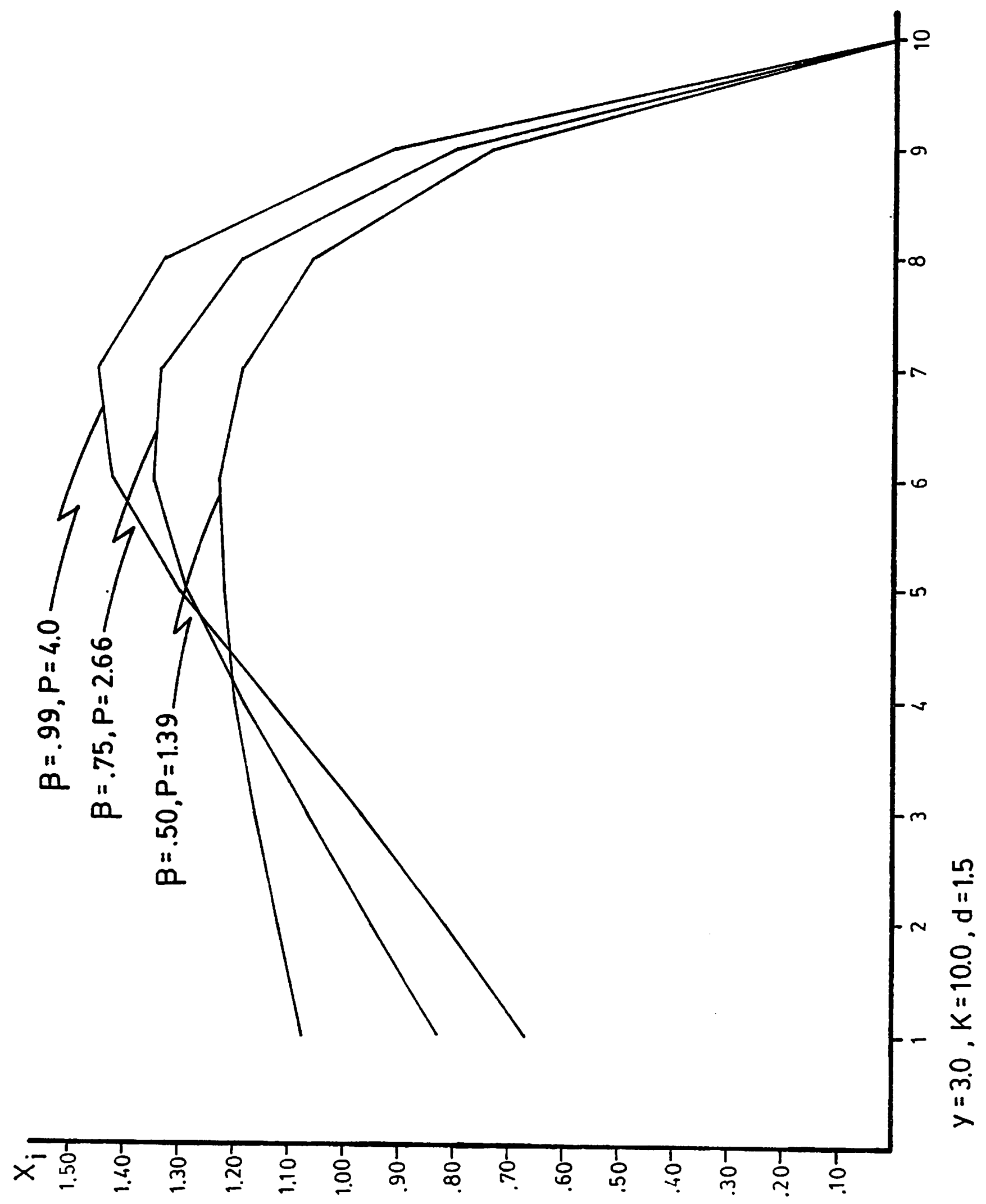

$N$
$w$
$\frac{u}{J}$
$\frac{0}{L}$
$\frac{L}{L}$ 
Hence, it is clear that the price of capital depends upon the distribution of capital among the population. This point bears emphasizing. The quantity of capital held by an agent is determined by the constraints which the agent has faced in the past. But these past decisions influence the price of capital today. This phenomenon is absent in the traditional models of asset pricing: past decisions are generally irrelevant.

This has intriguing implications for trading volume as well. Equation (14) combined with equations (9) and (11) imply that the volume of trade in any period depends upon existing holdings of capital as well as the price of capital. But since, as previously described, the price of capital depends upon existing holdings of capital, trading volume in any period will be a function of past decisions of agents in the economy.

In summary, the economy described above, which has a pricing function as displayed in equation (13), is likely to give rise to interesting dynamic and serial correlation properties for both the price of capital and the amount of capital traded. Since equation (13) is somewhat cumbersome, this is best illustrated with the use of examples. Figures (3), (4), and (5) show the outcome of a simple impulse-response experiment for a sample economy. Agents are assumed to live for 10 periods and initially the economy is in a steady state, where all stochastic and non-stochastic variables assume their stationary values. ${ }^{2}$ Then, at time $t=1$, the realization of $\left(y_{t}\right)$ is doubled from its previous level of 5.0 to 10 units, thereafter it returns to its old level of 5.0. This permits the study of exactly how the economy will react to this shock alone. Note that because expectations do not appear in equation (13), this experiment is indeed a dynamic analysis. Figure (3) shows that the price of capital jumps immediately and stays above its steady state level for several periods before falling below this level. 


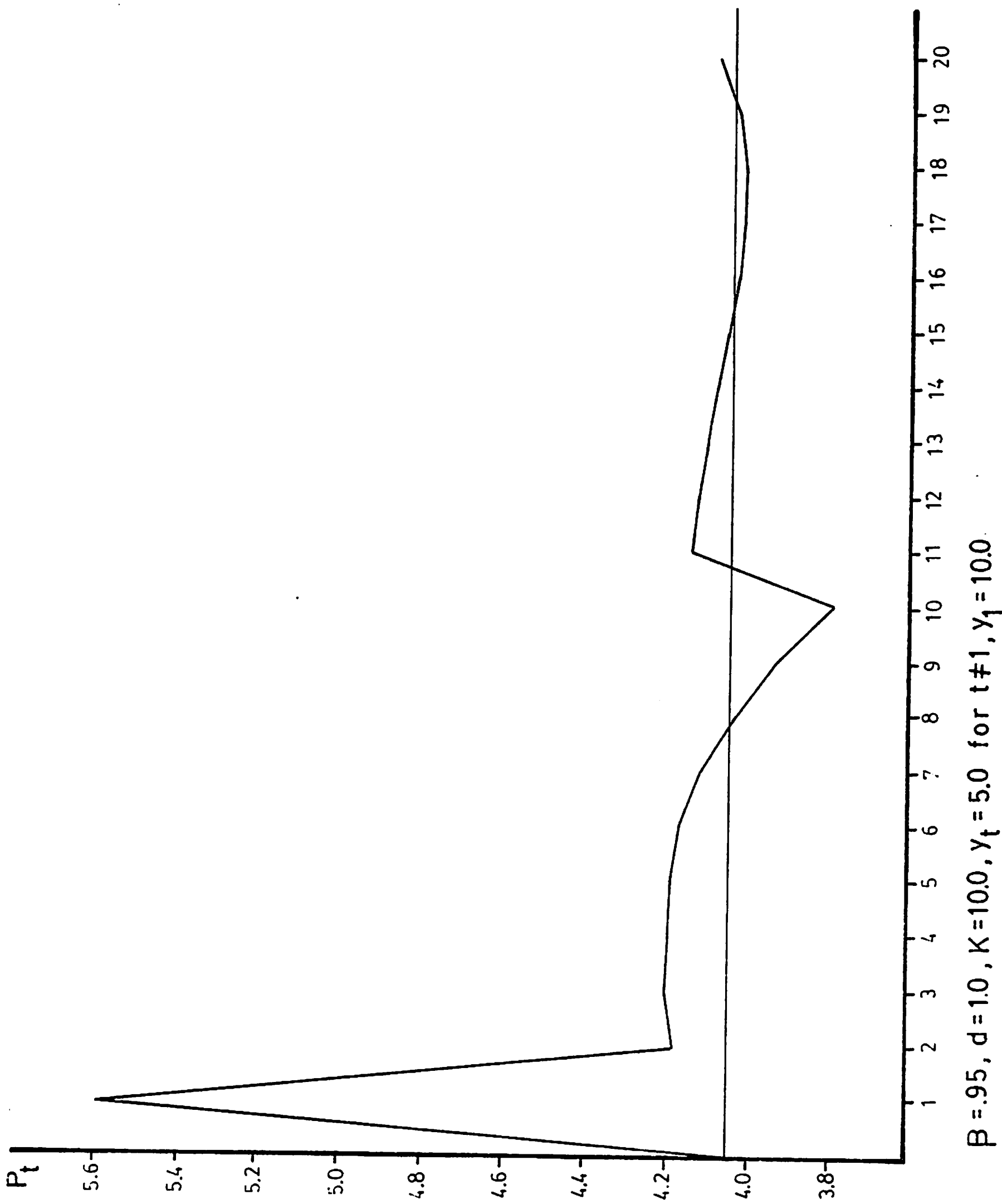

$m$
$\frac{1}{\sigma}$
$\frac{5}{4}$ 


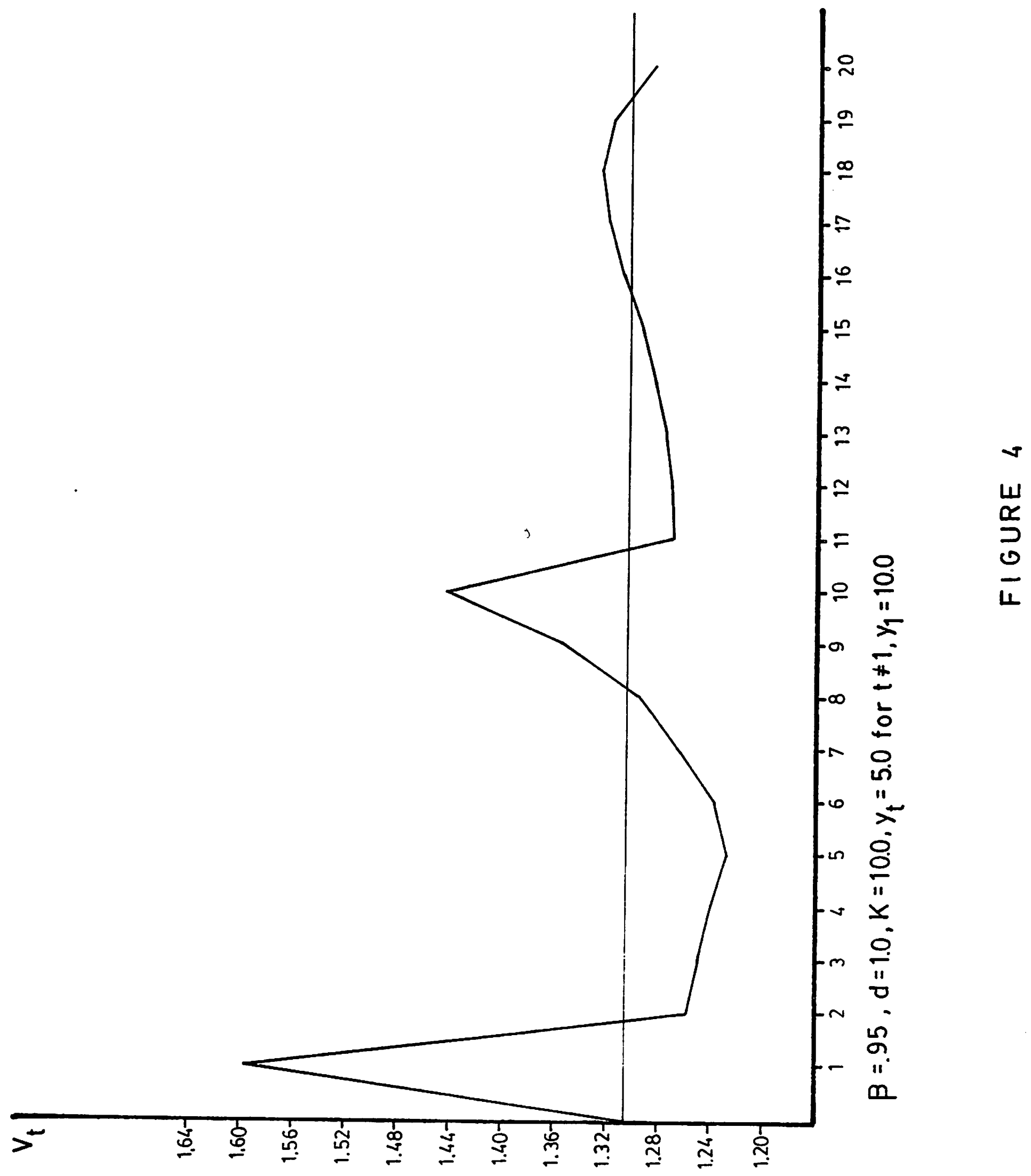




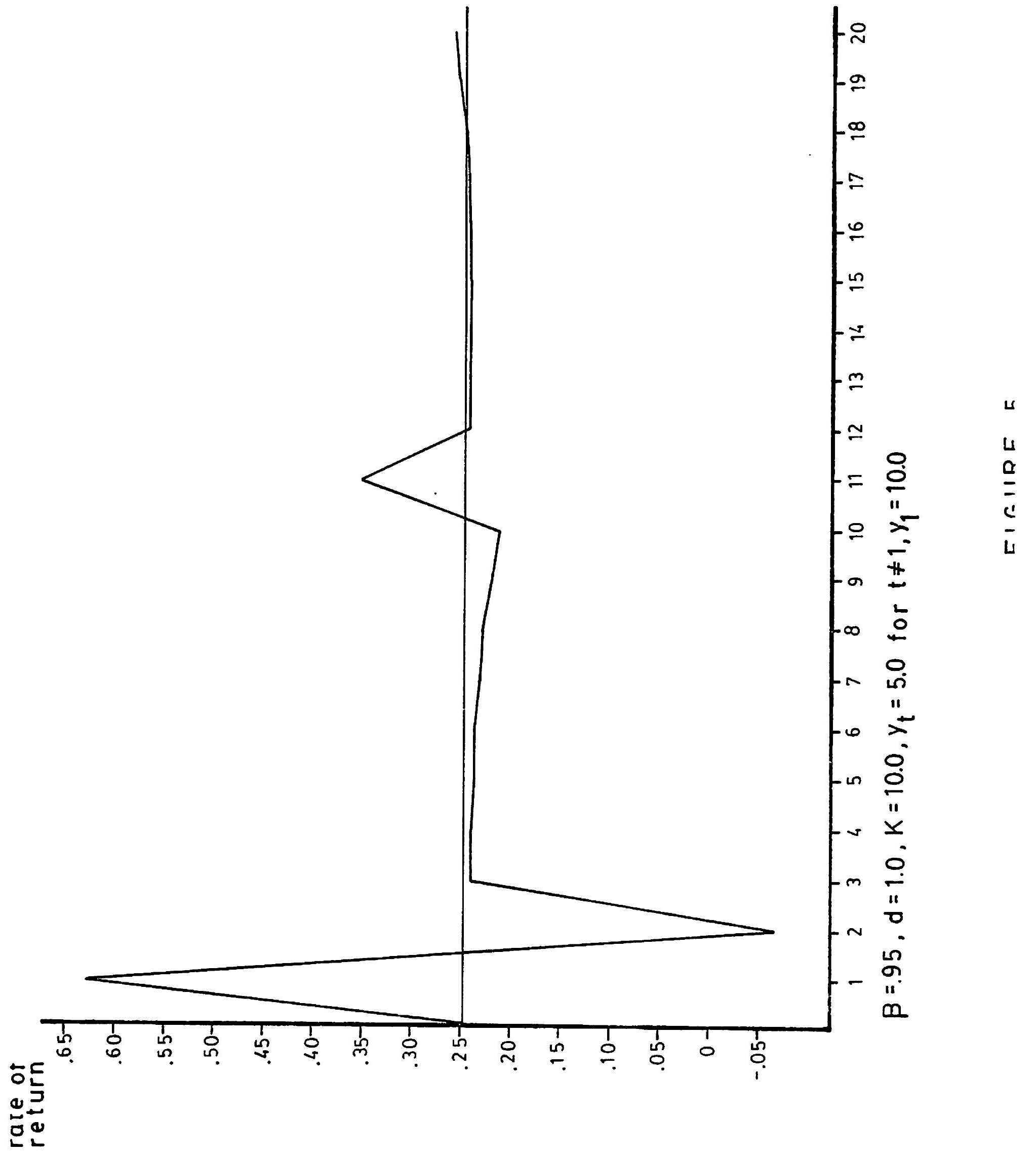


Thereafter the price of capital exhibits oscillations converging to its steady state level. Figure (4) shows how the volume of trade responds to the same shock. Initially, this volume rises substantially. Intuitively, this is due to the young agents, who wish to consume more in future periods, purchasing capital which can be sold in the future. These agents will then slowly sell this capital in order to smooth consumption throughout their lifetime. Since they will sell it off gradually, the volume of capital traded falls immediately after period 1. As these agents who received this large endowment in period 1 begin to sell off their holdings of capital, the amount of capital traded tends to rise. In Figure (4) this happens in periods 6 through 10 . The volume of trade peaks in period 10 because the agents born in period 1 are forced to sell off all remaining holdings of capital. Figures (3) and (4) together exhibit coincident, although negatively correlated, behaviour. The initial shock causes both the price and trade volume to' rise. Thereafter these variables are negatively correlated. As the economy approaches period 10, more capital is being supplied and consequently its price is falling. Agents fortunate enough to be entering the market in period 10 can purchase capital at a price which is lower than the economies' steady state level. Hence these agents can be expected to have a higher level of lifetime consumption than the "average" agent in the economy. That is, these agents are going to be "better off" in a way similar to those agents born in period $t=1$. Therefore prices stay above trend and trade volume stays below trend immediately after period 10 . The economy then proceeds to exhibit convergent cycles after period 10 which are similar to those which appeared immediately after period (1). Figure (5) illustrates how the rate of return on capital oscillates due to the same shock. 
There are two other interesting features which this economy exhibits. First, the dynamic intertemporal movement in the price transactions volume, and rate of return persists long after the agents who received the initial shock have left the economy. In Figures (3), (4) and (5), these agents leave the economy in period 10 , but the price, transactions volume, and rate of return have not attained their steady state levels in period 20 . This illustration shows how past decisions of agents influence present behaviour of variables which are determined endogenously in this asset market. Secondly, a very moderate amount of intuition suggests that the periodicity of the cycles in Figures (3), (4) and (5) is related to the number of periods that agents participate in asset market. That is, as agents live for a shorter time, the frequency of the oscillations in Figures (3), (4) and (5) should become higher. Similarly, the frequency should become smaller as agents become longer lived. Hence the frequency of the movements in the price of capital and the amount of capital traded is related to the length of the planning horizon of the typical agent of the economy.

If the size of each generation were a random variable, a change in the quantity of people entering this market will have persistent effects. In fact, for the economy described in Figures (3)-(5), if endowments are held constant but the size of the first generation is doubled in period (1), and the size of all future generations is the same as those born prior to period (1), then the effect on the aggregate variables will be those shown in these same figures. Hence, the asset market can exhibit variable lagged responses to changes in endowments and to changes in the number of agents participating in this market.

Figures (6), (7) and (8) illustrate a similar experiment to that of the previous two diagrams. In these figures the economy is again in a steady 


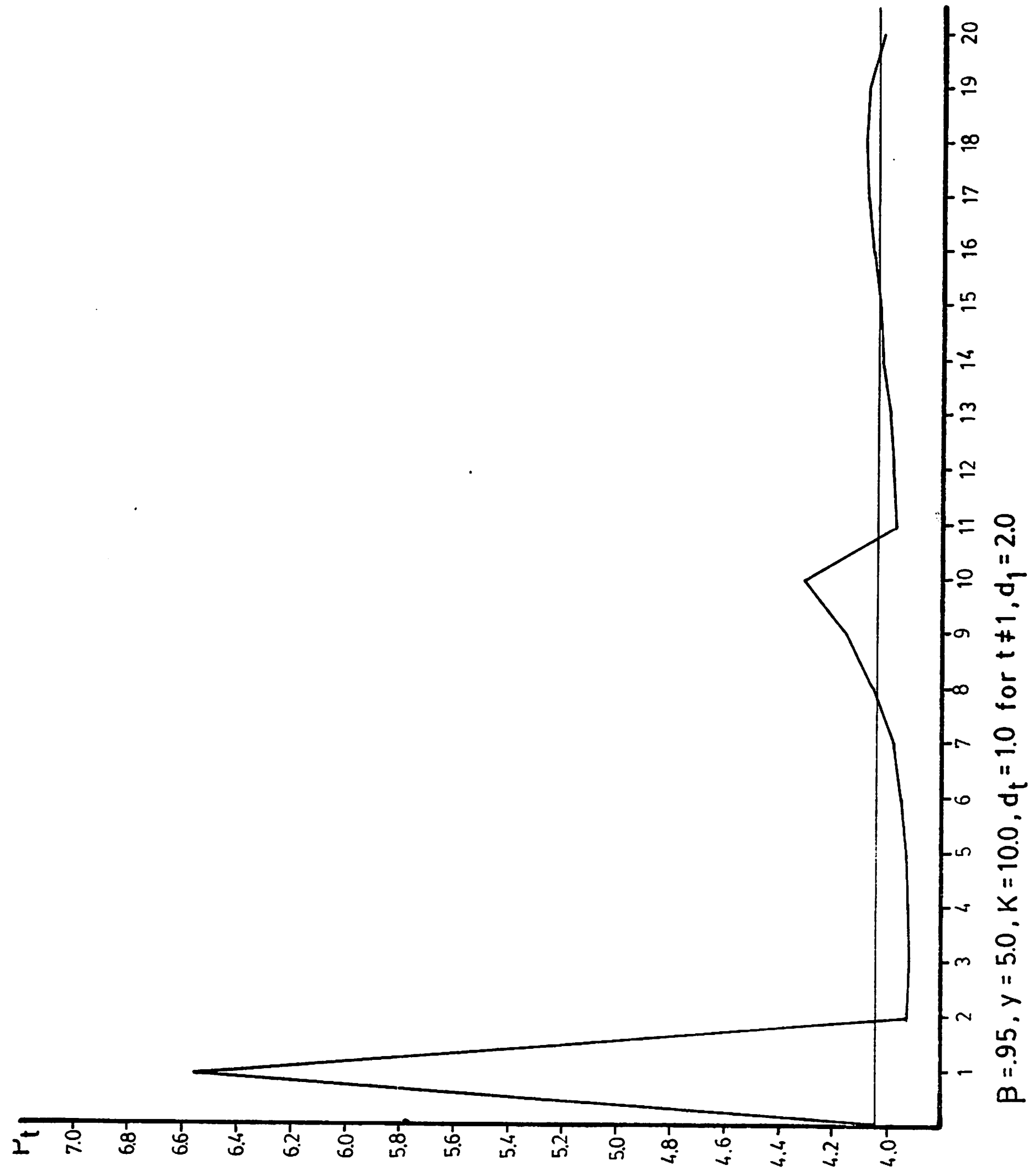

4
$U$
0
$Z$
C
L 
23

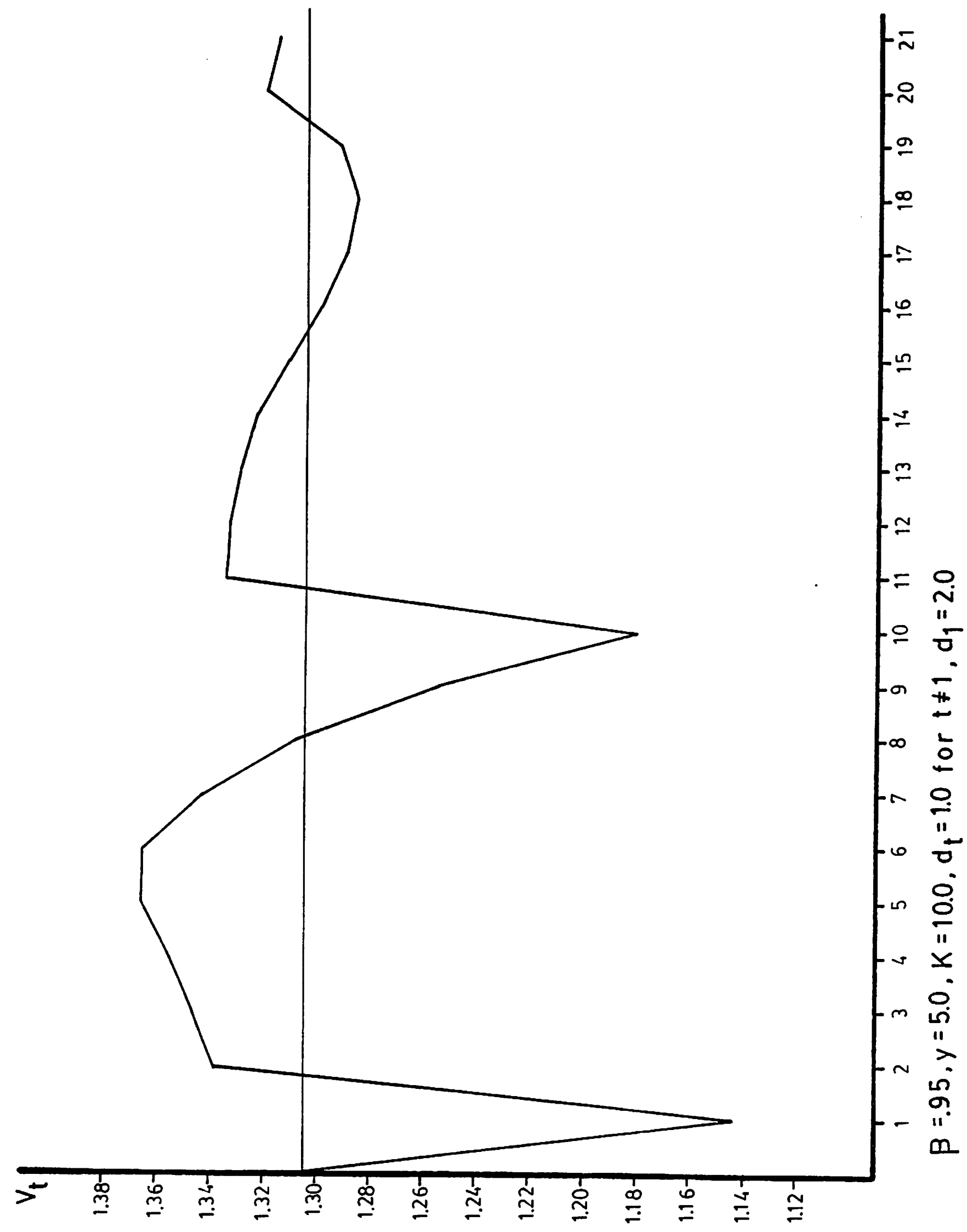

$\omega$
$\omega$
$\frac{1}{0}$
$\frac{0}{4}$ 


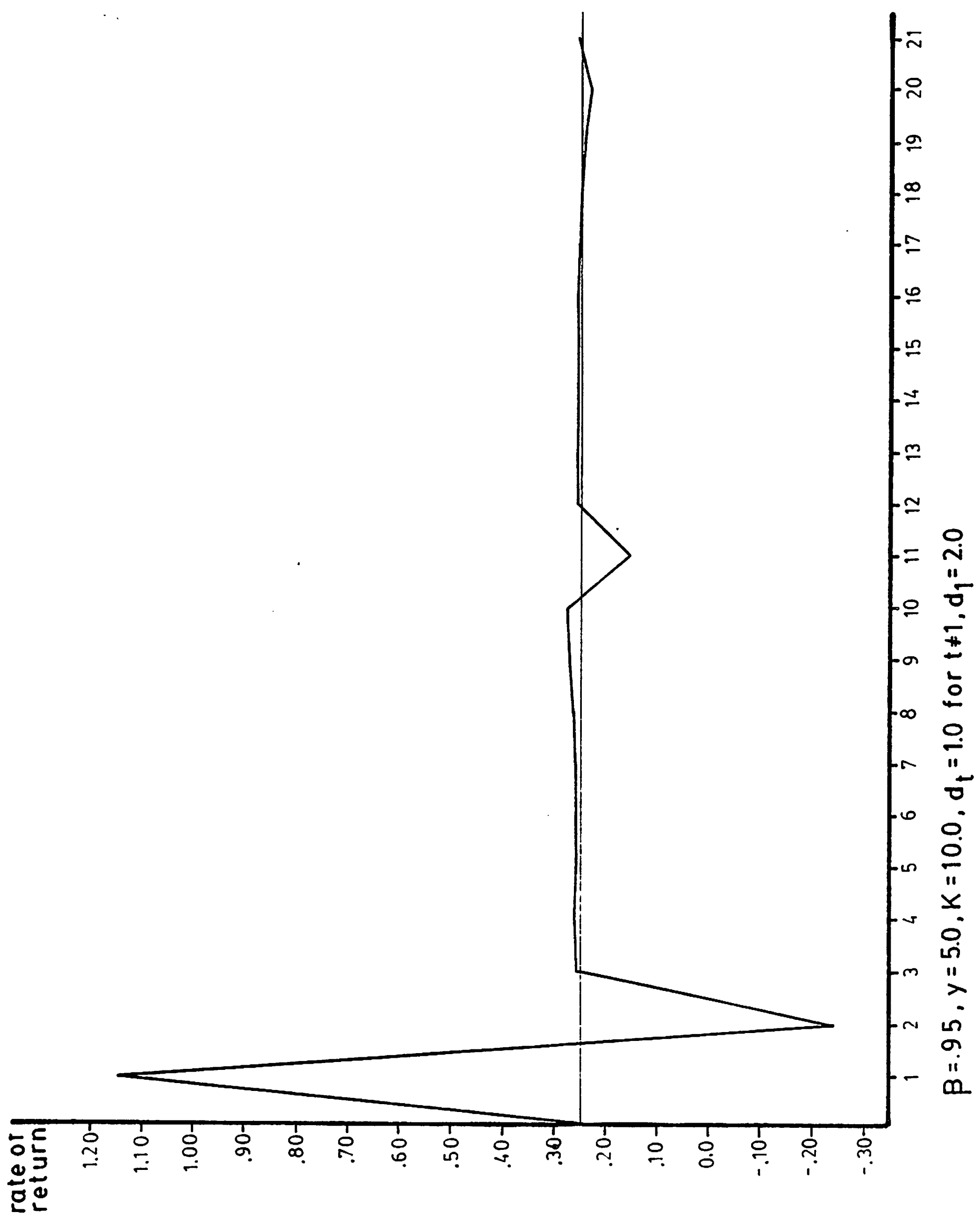


state until time $t=1$, with all variables assuming their stationary values. At time $t=1$ the level of dividends per unit of capital rises from 1.0 to 2.0 , whereupon it returns to a value of 1.0 for $t=2,3, \ldots$. Again the initial shock causes the price of capital to jump, because of the high yield. similarly the volume of trade falls because of the high return to holding capital. However, because future dividends are lower than at time $t=1$, there is more capital sold (and therefore purchased) immediately after period $t=1$. That is, agents do not sell as much capital in period $t=1$ as they otherwise would have if the dividend had been lower. But since dividends subsequently return to their old level thereafter, consumers compensate for not selling capital in period $t=1$ by selling larger quantities after this period. Hence the price of capital falls below its stationary level when trade volume rises above its stationary level. The decrease in volume and increase in price around period $t=10$ are also of considerable interest. Agents born in period $t=1$ do not purchase as much capital in this first period as did their predecessors because other agents in the economy wish to cut back on the quantity of capital sold in period $t=1$, because of the higher dividend. Consequently, agents entering the market in period $t=1$ have less capital to sell off throughout their lifetime. Hence, as the economy appproaches period $t=10$, there is less capital being sold (Figure (7)) and this causes the price of capital to rise (Figure (6)). Figure (8) also shows that the shock to dividends causes the rate of return to rise sharply, then fall sharply, and thereafter oscillate around the steady state. As in Figures (3), (4) and (5), Figures (6), (7) and (8) exhibit cylces after period (10) similar to those after period $t=1$. Figures (6) and (7) show that the price of capital and the volume are negatively correlated over most phases of the cycle. When the 
price of capital reaches a peak, the volume of trade reaches a trough, and vice versa. As with the previous experiment, the price of capital and trade volume exhibit cycles whose frequency is related to the length of the planning horizon of the agent. In addition the shock to the economy induces convergent oscillatory cycles which last longer than the planning horizon of any one agent.

It is instructive to pause at this point to compare the results from these dynamic experiments with similar experiments conducted in other general equilibrium models of asset pricing. Consider either the representative agent model of Lucas (1978) or the two period lived overlapping generations model, as described by Huberman (1984). Within the context of either of these models, consider a one-period shock to either dividends or non-capital endowments. Further, suppose the shock does not have any predictive content for future disturbances. In these models, there would be a change in the price of capital, which would immediately return to its otherwise assumed value in the subsequent period. That is, the price of capital would change in one, and only one period. This stands in contrast to the behaviour shown in Figures (3) and (6). As mentioned above, it is futile to ask what other general equilibrium models imply about the effect such a shock would have on trade volume. This is because in the representative agent model the trade volume is effectively zero, and in the two-period lived overlapping generations model trade volume is constant and equal to the total quantity of capital (i.e. each unit of capital is traded every period). That is, existing models have no implications for the determinants of trading volume over time.

Tables (1) and (2) show the statistics gathered from specific formulations of the model. Specific values have been chosen for the capital 


\section{Table 1}

$$
\begin{gathered}
X=10, \quad D=3.0, \quad \beta=.95 \\
\log \left(Y_{t}\right) \sim \mathbb{N}(1.10,0.5)
\end{gathered}
$$

$$
\begin{aligned}
& \left(\frac{v_{t}}{v_{\Delta P_{t}^{+} I}^{t}}\right)=6.46 \\
& \frac{v_{t}}{\left(\frac{t}{\Delta P_{t}^{-}}\right)}=6.41
\end{aligned}
$$

Wilcoxon ' $z$ ' - statistic $=2.89$

$$
\begin{aligned}
&\left|\Delta P_{t}\right|= .325+.38\left(v_{t}\right) \\
&(.100)(.060) \\
& .\left(\Delta P_{t}\right)^{2}=-0.89 \\
&(.286)+1.43\left(v_{t}\right) \\
&(.172) \\
& \Delta P_{t} \equiv P_{t}-P_{t-1}
\end{aligned}
$$

Standard errors are in parentheses. 


\section{Table 2}

$$
\begin{gathered}
K=10, \quad Y=10.0, \quad \beta=.95 \\
\log \left(d_{t}\right) \sim \mathbb{W}(0.0,0.15)
\end{gathered}
$$

$$
\begin{aligned}
& \left(\overline{\frac{V_{t}}{V_{\Delta P_{t}^{+}}^{+}}}\right)=26.5 \\
& \overline{\left(\frac{V_{t}}{V_{\Delta P_{t}^{-} \mid}}\right)}=19.0
\end{aligned}
$$

Wilcoxon ' $z$ ' - statistic $=1.41$

$$
\begin{aligned}
& \left|\Delta P_{t}\right|=.470+.038\left(v_{t}\right) \\
& \text { (.207) (.147) } \\
& \left(\Delta P_{t}\right)^{2}=.448-.010\left(v_{t}\right) \\
& \text { (.327) (.233) } \\
& \Delta P_{t} \equiv P_{t}-P_{t-1}
\end{aligned}
$$

Standard errors are in parentheses. 
stock and discount factor. In Table (1) the non-dividend endowment is stochastic while the dividend is fixed. In Table (2) the dividend is stochastic while the non-dividend endowment is fixed. In each case 1000 observations were generated from the model, and subsequent statistics were calculated from these observations.

Epps (1975) has attempted to test whether the ratio of trade volume to the absolute value of price changes is greater when prices rise than when prices fall. He finds support for the fact that the distribution of this ratio is different when prices rise than when prices fall. In Tables (1) and (2) the average values of the ratio of trade volume to the change in price has been calculated for the periods when prices fall $\left(\frac{\bar{t}_{\left|\Delta P_{t}^{-}\right|}^{V_{t}}}{{ }_{t}}\right)$ and when prices rise $\left(\frac{V_{t}}{\left|\Delta P_{t}^{+}\right|}\right)$. In both cases, the samples indicate that this ratio is higher for increases in prices.

The Wilcoxon 'z'-statistic (see Mood and Graybill (1963)) yields a ' $z$ '-statistic which is a test of the hypothesis that the distribution of $\left(\frac{v_{t}}{\left|\Delta P_{t}^{-}\right|}\right)$is the same as that of $\left(\frac{v^{t}}{\left|\Delta P_{t}^{+}\right|}\right)$.

The results show that this hypothesis can be rejected at the $99.8 \%$ confidence level for the economy in Table (1), but is rejected at only the $92 \%$ confidence level for the economy of Table (2). 
Tauchen and Pitts (1983) have found evidence to suggest that the magnitude of changes in stock prices is postively related to the volume of trade over the same period. Table (1) suggests that this relationship can be produced when the primary shocks to the economy are induced through the non-dividend endowment. Table (2) suggests that when dividends are stochastic, there is no relationship between these two variables. This seems to be in accord with one's intuition when Figures (6) and (7) are taken into consideration.

\section{v. Excess Price Variability}

It has been well-documented that the prices of certain assets tend to exhibit an excessive amount of variability when viewed within the context of certain economic models. In turn various reasons have been given to explain this apparent anomaly. The model presented here would yield price variability which would be difficult to rationalize within the context of other models.

To illustrate this, consider the experiment which gave rise to the behaviour of prices shown in Figure (3). To recapitulate, there is an endowment shock in period (1) which causes prices to oscillate for many periods. Now consider a financial economist who has heretofore modelled financial markets using the framework of Lucas (1978) and is studying the data which he receives concerning this economy. In particular, the economist observes data on aggregate consumption, the price of capital, and dividends. The economist, while looking at Figure (3) may conclude that the rise in aggregate consumption could have caused the price level to rise in period (1). However, the behaviour of the price of capital from period (2) onward may be seen as perverse because there is no change in dividends or aggregate 
consumption. The economist might then conclude that the price of capital exhibits excessive variability. In addition, the serial correlated nature of the price may be looked upon as still another anomaly. In conclusion, such an economist might conclude that there was something perverse or wrong with this financial market.

Nothing could be further from the truth. Such a view comes from a predisposition as to the nature of the optimization problem faced by agents in the economy. An economist who wishes to model the economy, whose behaviour in Figures (3)-(5), through the use of an infinitely-lived representative agent model, will face a very difficult task. ${ }^{3}$ The present study indicates that previous work, which has used the infinitely-lived representative agent model or the two period-lived overlapping generations model, has ignored the determinants of transaction volume and has thereby also ignored an important factor which is capable of producing price variability. It may be that a better understanding of the determinants of asset-price variability can be gained only by also gaining a better understanding of the determinants of transaction volume.

The variability in the price of capital is not induced through irrationality, liquidity constraints, corner solutions, changes in risk-aversion, or non-stationarity of the equilibria. Furthermore, it has become somewhat popular to consider "speculative bubbles" or self-fulfilling expectations as being responsible for price variability which is apparently unattributable to real factors such as aggregate consumption. In the examples of this paper, however, the variability in prices, which is seemingly unrelated to variations in real aggregate variables, is not attributable in any way to elements of expectations. 


\section{vI. Final Remarks}

A dynamic general equilibrium model has been constructed in which agents have arbitrary but finite lifetimes. The asset-pricing formula which is derived in such an economy exhibits some interesting features when agents live for more than two periods. In this case agent's current holdings of capital, which were determined in previous periods, become a fundamental determinant of the price of capital. Disturbances in the economy, such as an endowment shock, have an effect upon the price of capital and individual portfolios. Because portfolio decisions made in one period can influence the price of capital in successive periods, such disturbances can have a prolonged influence on the economy. In other words, the heterogeneity of the population can act as a propagation mechanism such that certain shocks can have an effect on the economy over an extended period of time. In the financial market of this model a one-period shock can yield serially correlated changes in the price of capital, the rate of return on capital, and the volume of capital traded. In addition, the frequency of the cycles which these variables display is related to the length of the planning horizon of the agents in the economy. These financial market variables then exhibit variability which is not attributable to contemporaneous changes in real aggregate variables. Instead, a real shock can have individual-specific wealth effects which influence financial market variables for many periods in the future.

A novel feature of this environment is that the volume of trade is an endogenous stochastic variable in a dynamic equilibrium. Shocks to endownents, will have different effects upon the behaviour of trade volume in the future than will changes in dividends. 


\section{Footnotes}

${ }^{1}$ Care must be taken in defining the concept of aggregate transactions volume. Clearly not each purchase of an asset should contribute in the same manner to this calculation. For otherwise, agent $A$ could sell a unit of an asset to agent B who could immediately sell it back to agent $A$ in the same period. Since essentially nothing of substance has transpired, it makes sense to say that these transactions did not contribute to aggregate volume. If transactions of this sort were counted aggregate volume could be said to be indeterminate in practically any model.

2 This will permit the analysis of the impact of the endowment shock alone. The effects shown in Figures (2)-(4) are not in any way attributable to previous distributional effects or to other disturbances.

3 The obvious clue to the researcher that he was not using the appropriate model was that an implication of the infinitely-lived representative agent model is trade volume is zero. Clearly this does not correspond with the observed data. 


\section{$\underline{\text { References }}$}

Epps, Thomas $\omega .$, "Security Price Changes and Transaction Volumes: Theory and Evidence," 65 (September 1975): 586-597.

Epps, Thomas H., and Mary Lee Epps, "The Stochastic Dependence of Security Price Changes and Transaction Volumes: Implications for the Mixture-of-Distributions Hypothesis," Econometrica 44 (March 1976): $305-321$.

Huberman, Gur, "Capital Asset Pricing in an Overlapping Generations Model," Journal of Economic Theory 33 (August 1984): 232-248.

Huffman, G. W. "Asset Pricing with Capital Accurmulation," University of Western Ontario Research Report $\$ 8404$ (1984).

Huffman, G. W. "Asset Pricing with Heterogeneous Agents," University of Western Ontario Working Paper (1985).

Lucas, Robert E. Jr., "Asset Prices in an Exchange Economy," Econometrica 46 (November 1978): 1429-1445.

Merton, R. C., "An Intertemporal Capital Asset Pricing Model," Econometrica 41 (September 1973): 867-887.

Mood, A., and F. Graybill, Introduction to the Theory of Statistics, 2nd Ed., New York, (1963)

Tauchen, George E., and Mark Pitts, "The Price Variability-Volume Relationship on Speculative Markets," Econometrica 51 (March 1983): 485-505. 
8101C Markusen, James R. Factor Movements and Commodity Trade as Compliments: A Survey of Some Cases.

8102C . Conlon, R.M. Comparison of Australian and Canadian Manufacturing Industries: Some Empirical Evidence.

$8103 C$

Conlon, R.M. The Incidence of Transport Cost and Tariff Protection: Sme Australian Evidence.

B104C

Laidler, David. On the Case for Gradualism.

8105C

Wirick, Ronald G. Rational Expectations and Rational stabilization Policy in an Open Economy

$8106 C$

Mansur, Ahsan and John Whalley Numerical secification of Applied General Equilibrium Models: Estimation, Calibration, and Data.

$8107 C$

8108C D SU

8109C D SU

81100

$8111 C$

$8201 C$

$8202 C$

$8203 C$

$8204 C$

$8205 C$

$8206 C$

$8207 \mathrm{C}$

$8208 C$

8209C DSU

Burgess, David F., Energy Prices, Capital Formation, and Potential GNP

Jimenez, E. and Douglas $\mathrm{E}$ Keare. Busing Consumption and Income in the Low Income Uxban Setting:. Estimates from Panel Data in El Salvador

Whalley, John Labour Migration and the North-South Debate'

Manning, Richard and John McMillan Government Expenditure and Comparative Advantage

Freid, Joel and Peter towitt Why Inflation Reduces Real I nterest Rates

$\underline{1982}$

Manning, Richard and James R. Markusen Dynamic Non- Substitution and Long Run Production Possibilities

Feenstra, Robert and Ken Judd Tariffs, Technology Transfer, and Welfare

Ronald $w$. Jones, and Douglas D. Purvis: International Differences in Response to Common External Shocks: The Role of Purchasing Power Parity

James A Brander and Barbara J. Sencer: Industrial Strategy with Committed Firms

Whalley, John, The North-South Debate and the Terms of Trade: An Applied General Equilibrium Approach

Roger Betancourt, Christopher Clague, Arvind Panagariya CAPI TAL UTIIIZATI ON IN GENERAI DQUIITBRIUM

Mansur, Ahsan if On the Estimation of Import and Export Demand Elasticities and Elasticity Pessimism.

Whalley, J. and Randy Wigle PRICE AND QUANTITY RIGIDITIES IN ADJUSTMENT TO TRADE POLICY CHANGES: ALTERNATIVE FORMULATIONS AND INITIAL CALCULATIONS

JImenez, E. SQUATTING AND COMMNITY ORGANIZATION IN DEVELOPING COUNTRIES: A CONCEPTUAL FRAMEWORK 
8210C Grossman, G.M. INTERNATIONAL COMPETITION AND THE UNIONIZED SECTOR

8211C LaIdler,D. FRIEDMAN AND SCHWARTZ ON MONETARY TRENDS - A REVIEH ARTICLE

8212C Imam, M.A: and Whalley, J. INCIDENCE ANALYSIS OR A SECTOR SPECIFIC MINIMUM
WAGE IN A TWO SECTOR BARRIS-TODARO MODEL.

8213C Markusen, J.R. and Melv1n, J.R. THE GAINS FROM TRADE THEOREM WITH INCREASING
RETURNS TO SCALE.

8214C INDUSTRIAL ORGANIZATION AND THE GENERAL EQUILIBRIUM COSTS OF PROTECTION IN
SMALL OPEN ECONOMIES.

8215C Laldlex, D. DID MACROECONOMICS NEED THE RATIONAL EXPECTATIONS REVOLUTION?

8216C Whalley, J, and WIgle, R. ARE DEVELOPED COUNTRY MULTILATERAL TARIFF

$8217 \mathrm{C}$ Bade, R. and Parkin, M. IS STERLING M3 THR RIGHT AGGREGATE?

$8218 \mathrm{C}$ ROSCh, B. FIXED PRICE EQUIIIBRIA IN OPEN ECONOMIES.

8301C Kimbell, L.J. and Harrison, G.W. ON THE SOLUTION OF GENERAL EQUILIBRIUM
MODELS.

8302C Melvin, J.R. A GENERAL EQUILIBRIUM ANALYSIS OF .CANADIAN OIL POLICY.

8303C Markusen, J.R. and Svensson, L.E.O. TRADE IN GOODS AND FACTORS WITH

8304C Mohammad, S. Whalley, J. RENT SEEKING IN INDIA: ITS COSTS AND POLICY
SIGNIFICANCE.

8305C DSU Jimenez, E. TENURE SECURITY AND URBAN SQUATTING.

8306C Parkia, M. WHAT CAN MACROECONOMIC THEORY TELL US ABOUT THE WAY DEEICITS
SHOULD BE MEASURED.

$8307 \mathrm{C}$ Parkin, M. THE INFLATION DEBATE: AN ATTEMPT TO CLEAR THE AIR.

$8308 \mathrm{C}$ Wooton, I. LABOUR MIGRATION IN A MODEL OF NORTH-SOUTH TRADE.

8309C Deardorff, A.V. THE DIRECTIONS OF DEVELOPING COUNTRIES TRADE: EXAMPLES
FROM PURE THEORY. 8310C Manning, R. ADVANTAGEOUS REALLOCATIONS AND MULTIPLE EQUILIBRIA: RESULTS
FOR THE THREE-AGENT TRANSFER PROBLEM. 

$8311 C$ DSU Mohamad, S, and Whalley, J. CONTROLS AND THE INTERSECTORAL TERMS OF
TRADE IN INDIA.

8312C - Brecher, Richard A. and Choudhri, Ehsan U. NEW PRODUCTS AND THE FACTOR CONTENT OB INTERNATIONAL TRADE.

$8313 \mathrm{C}$ Jones, R.W., Neary, J.P. and Ruane, F.P. TWO-WAY CAPITAL FLOWS: CROSSHAULING IN A MODEL OP FOREIGN INVESTMENT.

$8314 C$ DSU Follain, J.R. Jr. and JImenez, E. THE DEMAND FOR HOUSING CHARACTERISTICS IN DEVRLOPING COUNTRIES.

8315C Shoven, J.B. and Whalley, J. APPLIED' GENERAL EQUILIBRIUM MODELS OF TAXATION AND INTERNATIONAL TRADE.

8316C Boothe, Paul and Longworth David. SOME IRREGULAR REGULARITIES IN THE CANADIAN/U.S. EXCHANGE MARKET.

$8317 \mathrm{C}$ Hamilton, Bob and Whalley, John. BORDER TAX ADJUSTMENTS AND U.S. TRADE.

8318C Neary, J. Peter, and Schwelnberger, Albert G. FACTOR CONTENT FUNCTIONS AND IHE THEORY OF INTERNATIONAI TRADE.

8319C Veall, Michael R. THE EXPENDITURE TAX AND PROGRESSIVITY.

8320 C Melvin, James R. DOMESTIC EXCHANGE, TRANSPORTATION COSTS AND INTERNATIONAL TRADE.

$8321 \mathrm{C}$ Hamilton, Bob and Whalley, John. GEOGRAPHICALLY DISCRIMINATORY TRADE ARRANGEMENTS.

$8322 \mathrm{C}$ Bale, Harvey Jr. INVESTMENT FRICTIONS AND OPPORTUNITIES IN BILATERAL U.S.-CANADIAN TRADE RELATIONS.

$8323 \mathrm{C}$ Wonnacott, R.J. CANADA-U.S. ECONOMIC RELATIONS-A CANADIAN VIEW.

8324C Stern, Robert M. U.S.-CANADIAN TRADE AND INVESTMENT FRICTIONS: THE U.S: VIEH.

8325C Harrison, Glenn; H. and Kimbell, Larry, J. HOW ROBUST IS NUMERICAI GENERAL EQUILIBRIUM ANALYSIS?

8326C Wonnacott, R.J. THE TASK FORCE PROPOSAL ON AUTO CONTENT: WOULD THIS SIMPLY EXTEND THE AUTO PACT, OR PUT IT AT SERIOUS RISK?

8327C Bradford, James C. CANADIAN DEFENCE TRADE WITH THE U.S. Conklin, David. SUBSIDY PACTS.

Rugman, Alan M. THE BEHAVIOUR OF U.S. SUBSIDARIES IN CANADA:

IMPLICATIONS FOR TRADE AND INVESTMENTS. 
8328C Boyer, Renneth D. U.S.-CANADIAN TRANSPORTATION ISSUES.

8329C Bird, Richard M. and Brean, Donald J.S. CANADA-U.S. TAX RELATIONS: ISSUES AND PERSPECTIVES.

8330C Moroz, Andrew R. CANADA-UNITED STATES AUTOMOTIVE TRADE AND TRADE POLICY ISSUES.

8331C Grey, Rodney de C. and Curtis, John. INSTITUTIONAL ARRANGEMENTS FOR U.S.-CANADIAN IRGOTIATIONS. PART I: CANADA-U.S. TRADE AND ECONOMIC ISSUES: DO WE NEED A NEW INSTITUTION? PART II: INSTITUTIONAI ARRANGEMENTS fOR MaNAGING THE CANADA-U.S. ECONOMIC RELATIONSHIP.

\section{$\underline{1984}$}

8401C Harrison, Glenn $W$. and Manning, Richard. BEST APPROXIMATE AGGREATION OF INPUT-OUTPUT SYSTEMS.

8402C Parkin, Michael. CORB INFLATION: A REVIEN ESSAY.

8403C Blomqqist, Àke, and McMahon, Gary. SIMULATING COMMEICAL POLICY IN A SMALL, OPEN DUAL ECONOMY WITH URBAN UNEMPLOYMENT: A GENERAL EQUILIBRIUM APPROACH.

8404C Wonnacott, Ronald. THE THEORY OF TRADE DISCRIMINATION: THE IIIRROR IMAGE OF VINERIAN PREEERENCE THEORY?

8405C Whalley, John. IMPACTS OF A 50\% TARIFT REDUCTION IN AN EIGHT-REGION GLOBAL TRADE MODEL.

8406C Harrison, Glenn W. A GENERAL EQUIIIBRIUM ANALYSIS OF TARIFP REDUCTIONS.

8407C Horstmann, Ignatius and Markusen, James R. STRATEGIC INVESTMENTS AND THE DEVELOPMENT OF MULTINATIONALS.

$8408 C$ Gregory, Allan W. and MCCurdy, Thomas H. TESTING THE UNBIASEDNESS HYPOTHESIS IN :THE FORWARD FOREIGN EXCHANGE MARKET: A SPECIFICATION ANALYSIS.

8409 C Jones, Ronald 1. and Klerzkowsk1, Henryk. NEIGHBORHOOD PRODUCTION STRUCTURES WITH APPLICATIONS TO THE THEORY OF INTERNATIONAL TRADE.

$8410 \mathrm{CWeller,} \mathrm{Paul} \mathrm{and} \mathrm{Yano,} \mathrm{Makoto.} \mathrm{THE} \mathrm{ROLE} \mathrm{OF} \mathrm{FUTURES} \mathrm{MARKETS} \mathrm{IN}$ INTERNATIONAL TRADE: A GENERAL EỌUILIBRTUM APPROACH.

8411C Brecher, Richard A. and Bhagwat1, Jagdish N. VOLUNTARY EXPORT RESTRICTIONS VERSUS IMPORT RESTRICTIONS: A WELFARE-THEORETIC COMPARISON. 
8412C Ethler, W11fred J. ILLEGAL IMMIGRATION.

8413C Eaton, Jonathon and Gene M. Grossman. OPTIMAL TRADE AND INDUSTRIAL POLICY UNDER OLIGOPOLY.

$8414 \mathrm{C}$ Wooton, Ian. PREFERENTIAL TRADING AGREEMENTS - A 3xn MODEL.

8415C Parkin, Michael. DISCRIMINATJN, BETWEEN KEYNESIAN AND CLASSICAL TIEORIES OF THE BUSINESS CYCLE: JAPAN 1967-1982

8416C Deardorff, Alan V. FIRless FIRwoes: HOW PREFERENCES CAN INTERFERE WITH THE THEOREMS OF INTERNATIONAL TRADE.

8417C Greenwood, Jeremy. NONTRADED GOODS, THE TRADE BALANCE, AND THE BALANCE OF PAYRENTS.

8418C Blomqvist, Ake and Sharif Mohammad. CONTROLS, CORRUPTION, AND COMPETITIVE RENT-SEEKING IN LDCs.

$8419 \mathrm{C}$ Grossman, Herschel I. POLICY, RATIONAL EXPECTATIONS, AND POSITIVE ECONOMIC ANALYSIS.

8420C Garber, Peter M. and Robert G. King. DEEP STRUCTURAL EXCAVATION? A CRITIOUUE OF EULER EQUATION METHODS.

$8421 \mathrm{C}$ Barro, Robert J. THE BEHAVIOR OF U.S. DEFICITS.

8422C Persson, Torsten and Lars E.0. Svensson. INTERNATIONAL BORROWING AND TIME-CONSISTENT FISCAL POLICY.

8423C Obstfeld Maurice. CAPITAL CONTROLS, THE DUAL EXCHANGE RATE, AND DEVALUATION.

8424C Kuhn, Peter. UNION PRODUCTIVITY EFFECTS AND ECONOMIC EFFICIENCY.

8425C Hamilton, Bob and John Whalley. TAX TREATMENT OF HOUSING IN A DYNAMIC SEỌUENCED GENERAL EỌUILIBRIUM MODEL.

$\because 426 \mathrm{C}$ Hamilton, Bob, Sharif Mohammad, and John Whalley. RENT SEEKING AND THE NORTH-SOUTH TERMS OF TRADE.

8427C Adams, Charles and Jeremy Greenwood. DUAL EXCHANGE RATE SYSTEMS AND CAPITAL CONTROLS: AN INVESTIGATION.

8428 Loh, Choon Cheong and Michael R. Veall. A NOTE ON SOCIAL SECURITY AND PRIVATE SAVINGS IN SINGAPORE.

8429 Whalley, John. RFGRESSION OR PROGRESSION: THE TAXING OUESTION OF INCIDENCE ANALYSIS.

8430 Kuhn, Peter. WAGES, EFFORT, AND INCENTIVE-COMPATIBILITY IN LIFE-CYCLE EMPLOYMENT CONTRACTS. 
8431 Greenwood, Jeremy and Kent P. Kimbrough. AN INVESTIGATION IN THE THEORY OF FOREIGN EXCHANGE CONTROLS.

8432 Greenwood, Jeremy and Kent P. Kimbrough. CAPITAL CONTROLS AND THE INTERNATIONAL TRANSMISSION OF FISCAL POLICY.

8433 : Nguyen, Trien Trien and John Whalley. EṇUILIBRIUM UNDER PRICE CONTROLS WITH ENDOGENOUS TRANSACTIONS COSTS.

8434 Adams, Charles and Russell S. Boyer. EFFICIENCY AND A SIMPLE MODEL OF EXCHANGE RATE DETERMINATION.

8435 Kuhn, Peter. UNIONS, ENTREPRENEURSHIP, AND EFFICIENCY.

8436 Hercowitz, ZvI and Efraim Sadka. ON OPTIMAL CURRENCY. SUBSTITUTION POLICY AND PUBLIC PINANCE.

8437 Lenfosek, Gordon and John Whalley, POLICY EVALUATION IN A SMALL OPEN PRICE TAKING ECONOMY: CANADIAN ENERGY POLICIES.

8438 Aschauer, David and Jeremy Greenwood. MACROECONOMIC EFFECTS OF FISCAL POLICY.

8439C Hercowitz, Zvi. ON THE DETERMINATION OF THE EXTERNAL DEBT: THE CASE OF ISRAEL.

8440C Stern, Robert $M$. GLOBAI DIMENSIONS AND DETERMINANTS OF INTERNATIONAL TRADE AND INVESTMENT IN SERVICES.

$8441 \mathrm{C}$ Deardorff, Alan V. COMPARATIVE ADVANTAGE AND INTERNATIONAI TRADE AND INVESTMENT IN SERVICES.

8442C Daly, Donald J. TECHNOLOGY TRANSFER AND CANADA'S COMPETITIVE PERFORMANCE.

8443C Grey, Rodney de C. NEGOTIATING ABOUT TRADE AND INVESTMENT IN SERVICES.

8444C Grossman, Gene $M$. and Carl Shapiro. NORMATIVE ISSUES RAISED BY INTERNATIONAL TRADE IN TECHNOLOGY SERVICES.

8445C Chant, John F. THE CANADIAN TREATMENT OF FOREIGN BANKS: A CASE STUDY IN THE WORKINGS OF THE NATIONAL TREATMENT APPROACH.

8446C Aronson, Jonathan D. and Peter F. Cowhey. COMPUTER, DATA PROCESSING, AND COMMUNICATION SERVICES.

8447C Feketekuty, Geza. NEGOTIATING STRATEGIES FOR LIBERALIZING TRADE AND INVESTMENT IN SERVICES.

8448C Harrison, Glenn, W. and E.E. Rutstrom. THE EFFECT OF MANUFACTURING SECTOR PROTECTION ON ASEAN AND AUSTRAIIA: A GENERAL EṆUILIBRIUM ANALYSIS. 
$8501 C$

8502C Horstmann, Ignatius and James R. Markusen. UP YOUR AVERAGE COST CURVE: INEFFICIENT ENTRY AND THE NEW PROTECTIONISM.

8503C Gregory, Allan W. TESTING INIEREST RATE PARITY AND RATIONAL EXPECTATIONS FOR CANADA AND THE UNITED STATES.

8504C Kuhn, Peter and Ian Hooton. INTERNATIONAL FACTOR MOVEMENTS IN THE PRESENCE OF A FIXED FACTOR.

8505C Nong, Rar-yiu. GAINS FROM GOODS TRADE AND FACTOR MOBILITY.

8506C Weller, Paul and Makoto Yano. FUTURES MARKETS, REAL INCOME, AND SPOT PRICE VARIABIIITY: A GENERAL EQ̣UILIBRIUM APPROACH.

8507C Diewert, APPROACH.

8508C Ethier, Wilfred J. FOREIGN DIRECT INVESTMENT AND THE MOLTINATIONAL FIRM.

8509C Dinopoulos, Elias. INSIDE THE BLACK BOX: (IN)TANGIBLE ASSETS, INTRA-INDUSTRY INVESTMENT AND TRADE.

8510C Jones, Richard, John Whalley, and Randall Higle. REGIONAL IMPACTS OF TARIFFS IN CANADA: PRELIMINARY RESULTS FROM A SMALL DIMENSIONAL NUMERICAL GENERAL EOUUIL IBRIUM MODEL.

8511C Whalley, John. HIDDEN CHALLENGES IN RECENT APPLIED GENERAL EQUILIBRIUM EXERCISES.

8512C Smith, Bruce. SOME COLONIAL EVIDENCE ON TWO THEORIES OF MONEY: MARYLAND AND THE CAROLINAS.

3513C Grossman, S.J., A. Melino, and R.J. Shiller. ESTIMATING THE CONTINUOUS TIME CONSUMPTION BASED ASSET PRICING MODEL.

8514C Romer, Paul R. TAX EFFECTS AND TRANSACTION COSTS FOR SHORT TERM MARKET DISCOUNT BONDS.

8515C McCallum, Bennett T. ON CONSEOUUNCES AND CRITJCISMS OF MONETARY TARGETING.

8516C Dinopoulos, Elias and Ian Wooton. A NORTH-SOUTH MODEL OF INTERNATIONAL JUSTICE.

8517C Huffman, Gregory W. A DYNAMIC EQUILIBRIUM MODEL OF ASSET PRICES AND TRANSACTION VOLUME.

8518C Huffman, Gregory W. AN ALTERNATIVE VIEW OF OPTIMAL SEIGNIORAGE.

8519C Huffman, Gregory W. ASSET PRICING WITH HETERGENEOUS ASSETS. 


\section{$\underline{1985}$}

$8520 \mathrm{C}$ Hercowitz, Zvi. THE REAL INTEREST RATE AND AGGREGATE SUPPLY. 